\title{
Malagasy Language
}

National Cancer Institute

\section{Source}

National Cancer Institute. Malagasy Language. NCI Thesaurus. Code C154029.

An Austronesian language that is the national language of Madagascar. 